Check for updates

New York, USA

Cite this as: $B M J 2020 ; 371: \mathrm{m} 3897$ http://dx.doi.org/10.1136/bmi.m3897 Published: 06 October 2020

\section{Covid-19: Trump returns to White House amid confusion over his illness and treatment}

\author{
Janice Hopkins Tanne
}

President Donald Trump, although still infectious, was flown back to the White House on the evening of 5 October, to isolate and recover after spending three nights at Walter Reed National Military Medical Center for treatment of covid-19.

Trump's doctor, Sean Conley, said he was "not entirely out of the woods yet."

Trump tweeted, “Don't be afraid of covid. Don't let it dominate your life. We have developed, under the Trump Administration, some really great drugs \& knowledge. I feel better than I did 20 years ago!”

As he walked up the steps to the White House, the president pulled off his mask.

As of the evening of 5 October, the US had 7457263 cases and 210176 deaths from covid-19. ${ }^{1}$

Confusion remains over when Trump became ill, what treatments he is receiving, and why. He is 74 and obese, conditions that put him at increased risk. It is not clear how long he has been infected as the date of his last negative test for covid-19 is not known. It is five days since the apparent onset of symptoms, and covid-19 infections can worsen on days seven to 10, so some experts expressed concern over allowing him to return home, even though the White House has a medical clinic.

Trump announced at about 1 am on 2 October that he and his wife Melania had tested positive for covid-19. Since then at least 18 people on the White House staff or who had attended the 26 September reception for Amy Coney Barrett, Trump's Supreme Court nominee, have tested positive for covid-19, in a possible "super spreader" event. No contact tracing appears to have been done.

During 2 October Trump developed a cough, nasal congestion, a high fever, and a drop in oxygen saturation. He was given supplemental oxygen and was flown to Walter Reed medical centre in the early evening.

His White House doctor, Sean Conley, treated the president together with experts at the centre. Conley, a licensed osteopathic doctor, became the White House physician in 2018. He served in the US Navy as an emergency doctor and chief of trauma at a NATO medical unit in Afghanistan. ${ }^{2}$ Anthony Fauci, the head of the National Institute of Allergy and Infectious Diseases who has been a leader in the fight against covid-19, was not consulted.

During several press conferences Conley presented a positive picture of Trump's condition, which he later clarified by saying he wanted to support the Trump team's upbeat approach.
Conley said that Trump had two transient episodes of low oxygen saturation but would not say how low they had been. He said Trump's lung findings were as expected but did not say whether the president had had $\mathrm{x}$ rays or scans or what they had shown. He did not say how high his temperature had been when he was taken to the hospital.

Trump's treatment includes a five day course of intravenous remdesivir; an $8 \mathrm{~g}$ intravenous dose of REGN-COV2, a cocktail of antibodies to reduce viral load; the steroid dexamethasone, because of low oxygen saturation; and zinc, vitamin D, famotidine (a heartburn drug), melatonin, and aspirin. ${ }^{3} \mathrm{He}$ has not received hydroxychloroquine, which he previously promoted.

Remdesivir is not approved by the Food and Drug Administration (FDA) but is available under an emergency use authorisation for people hospitalised with severe covid-19. ${ }^{4}$ REGN-COV2, a combination of two antibodies, is an investigational drug now in clinical trials. It was apparently made available to treat Trump through a compassionate use application to the FDA. ${ }^{5}$ The World Health Organization has cautioned that dexamethasone should only be used in severe covid-19. ${ }^{6}$ The use of all three drugs together has not been reported before.

Lewis Kaplan, president of the Society of Critical Care Medicine and a surgeon at the hospital of the University of Pennsylvania, said the treatment may have been appropriate if Trump was severely ill, or he might be being overtreated as a VIP. ${ }^{7}$

On 4 October Trump made an unscheduled drive-by to wave at supporters who had gathered outside Walter Reed medical centre. James Phillips, a Walter Reed doctor and chief of disaster medicine at George Washington University, tweeted, "Every single person in the vehicle during that completely unnecessary presidential "drive-by" just now has to be quarantined for 14 days. They might get sick. They may die. For political theatre. Commanded by Trump to put their lives at risk for theatre. This is insanity."

Covid-19 dashboard by the Center for Systems Science and Engineering at Johns Hopkins University. https://gisanddata.maps.arcgis.com/apps/opsdashboard/index.html\#/bda7594740fd40299423467b48e9ecf6.

2 Waller A, Morales C. What to know about Sean Conley, the White House physician. New York Times. 3 October 2020. www.nytimes.com/2020/10/03/us/sean-conley-trump-doctor.html.

3 Howard J. Trump's covid-19 so far has caused high fever and drops in oxygen, doctors say. CNN. 4 October 2020

www.cnn.com/2020/10/04/health/trump-covid-19-course-of-illness-timeline-bn/index.html.

4 Medline Plus. Why is this medicine prescribed? https://medlineplus.gov/druginfo/meds/a620033.html\#: :text=Remdesivir\%20injection\%20is\%20used\%20to,spreading\%20in\%20the\%20body.

5 Regeneron. 6 July 2020. https://investor.regeneron.com/news-releases/news-release-details/regeneron-announces-start-regn-cov2-phase-3covid-19-prevention. 
6 World Health Organization. Corticosteroids for covid-19. 2 September 2020. www. who.int/publications/i/item/WHO-2019-nCoV-Corticosteroids-2020.1.

7 Feuer W. Doctors worry Trump could be "overtreated" for coronavirus because he's a VIP. 5 October 2020. www.cnbc.com/2020/10/05/doctors-worry-trump-could-be-over-treated-forcoronavirus-because-hes-a-vip.html. 